PRACE GEOGRAFICZNE

zeszyt 152, 2018, 55-66

doi: $10.4467 / 20833113$ PG.17.030.8253

Instytut Geografii i Gospodarki Przestrzennej UJ

Wydawnictwo Uniwersytetu Jagiellońskiego

\title{
LOKALIZACJA USEUG NOCLEGOWYCH W OTOCZENIU RYNKU STAREGO MIASTA W WARSZAWIE
}

\author{
Marta Derek, Karolina Dycht
}

\section{Location of accommodation services in the vicinity of the Old Town Market Square in Warsaw}

Abstract: The aim of the article is to characterize the accommodation base in the vicinity of the Warsaw's Old Town from the point of view of its location, category structure and prices for accommodation services. Although this area is the only tourist precinct in Warsaw ('tourist district'), for many years accommodation establishments were scarce here. The situation has changed since the development of sharing economy was launched. The study conducted in October and November of 2016 showed that on the area within a radius of $1 \mathrm{~km}$ from the centre of the Old Town Market Square there were as many as 225 establishments with about 1,500 beds. An important part of these places were apartments to rent from the website provided by the Airbnb. Although about $43 \%$ of accommodation establishments were located up to $300 \mathrm{~m}$ from the centre of the market, no clear relationship between a distance from the market and a number of apartments to rent was identified. This, however, might have been caused by a relatively small area chosen for the research. Finally, the study shows that the most expensive apartments to rent are located in the surroundings of the Old Town Market Square.

Keywords: accommodation, Warsaw Old Town, apartments to rent, Airbnb

Zarys treści: Celem artykułu jest charakterystyka bazy noclegowej w otoczeniu Rynku Starego Miasta w Warszawie z punktu widzenia lokalizacji, struktury rodzajowej oraz cen za usługi noclegowe. Zasięg przestrzenny badań objął teren wyznaczony przez ekwidystantę o promieniu 
$1 \mathrm{~km}$ od środka Rynku Starego Miasta. Inwentaryzacja usług noclegowych na Starym Mieście dotyczyła wszystkich typów zakwaterowania, bez względu na ich oficjalny status, w tym mieszkania na wynajem. Została ona przeprowadzona w listopadzie i grudniu $2016 \mathrm{r}$. z wykorzystaniem serwisów internetowych udostępniających informacje na temat świadczonych usług noclegowych. Badania wykazały, że badany obszar dysponuje ok. 1,5 tys. miejsc noclegowych zgromadzonych w 225 obiektach. Znaczna częśc tych miejsc oferowana jest w mieszkaniach i apartamentach na wynajem, udostępnianych w dużej mierze na portalu Airbnb. Choć ok. $43 \%$ obiektów noclegowych mieści się w odległości nie większej niż 300 m od środka Rynku Starego Miasta, nie zaobserwowano wyrá́nej relacji między odległością od rynku a liczbą mieszkań na wynajem. Wykazano natomiast, że najdroższe mieszkania znajdują się w bezpośrednim sąsiedztwie rynku.

Stowa kluczowe: usługi noclegowe, Stare Miasto w Warszawie, mieszkania na wynajem, Airbnb

\section{Wprowadzenie}

Obiekty noclegowe stanowią podstawowy element zagospodarowania turystycznego (Kowalczyk, Derek 2010). Są one najbardziej widocznym przejawem rozwoju turystyki w krajobrazie miast (Cohen-Hattab 2004). Ich rozwój na obszarach miejskich jest przedmiotem licznych studiów z zakresu geografii turyzmu i ekonomii. Do głównych kwestii problemowych związanych z analizą usług noclegowych w miastach należy diagnoza czynników ich rozwoju oraz lokalizacja. Badania podejmujące te zagadnienia są prowadzone w kilku kierunkach, m.in. w celu rozpoznania i oceny zakresu przestrzennego występowania hoteli za pomocą różnych miar centrograficznych (np. Matczak 2004; Rotter-Jarzębińska 2011; Adamiak, Napierała 2013; Nalej 2014), a także określenia relacji między lokalizacją obiektów hotelowych a jej uwarunkowaniami. Dużo uwagi poświęca się związkom pomiędzy cenami usług noclegowych a położeniem obiektów względem centrum miasta (np. Rotter 2004; Napierała, Adamiak 2014; Pawlicz, Napierała 2017). Ponadto podejmowane są zagadnienia ekonomiczne dotyczące lokalizacji hoteli w kontekście renty gruntowej (np. Egan, Nield 2000) oraz kwestie usytuowania obiektów noclegowych w relacji do innych elementów infrastruktury i zagospodarowania przestrzennego miasta. W toku dyskusji proponowane są różne ujęcia modelowe (np. Ashworth 1989; Kowalczyk 2001a, b), opisujące i wyjaśniające lokalizację obiektów hotelarskich na terenach miejskich (zob. np. Matczak 2004; Kowalczyk, Derek 2010; Rotter-Jarzębińska 2011; Włodarczyk 2015). Należy odnotować, że zdecydowana większość studiów z tego zakresu dotyczy bazy hoteli, znacznie rzadziej innych obiektów tworzących tzw. formalny sektor turystyki.

Lokalizacja mieszkań i apartamentów na wynajem, zaliczanych do sektora nieformalnego, nie była do tej pory przedmiotem szerszego zainteresowania geografów turyzmu (zwłaszcza w Polsce), pomimo że w wielu miastach te właśnie obiekty stają 
się dominującym elementem bazy noclegowej (Ashworth, Tunbridge 2000), zmieniając w ostatnich latach geografię usług noclegowych w miastach.

$\mathrm{Z}$ badań dotyczących lokalizacji usług noclegowych wynika, że jednym z najważniejszych obszarów ich koncentracji są historyczne centra miast. W Warszawie najważniejszym obszarem turystycznym („,dzielnicą aktywności turystycznej”) jest Stare Miasto (Derek 2018). W świetle oficjalnych danych (Centralna Ewidencja Usług Hotelarskich) na tym obszarze działają zaledwie dwa skategoryzowane hotele. Obserwacje wskazują, że obszar ten obfituje także w inne obiekty noclegowe. Jak dotychczas nie określono jednak skali rozwoju, struktury rodzajowej i lokalizacji tych obiektów w obrębie Starego Miasta w Warszawie. Równocześnie badania ruchu turystycznego w Warszawie wskazują, że aż 15\% turystów krajowych i 17\% turystów zagranicznych spało w wynajętym mieszkaniu lub apartamencie bądź korzystało z pokoju gościnnego lub kwatery prywatnej (Ipsos 2016). To pokazuje, że ranga tego sektora jest duża, a określenie skali opisywanego zjawiska może mieć istotne znaczenie zarówno teoretyczne, jak i aplikacyjne.

Celem artykułu jest charakterystyka bazy noclegowej w otoczeniu Rynku Starego Miasta w Warszawie z punktu widzenia lokalizacji, struktury rodzajowej oraz cen za usługi noclegowe. Zasięg przestrzenny badań wyznacza ekwidystanta długości $1 \mathrm{~km}$ poprowadzona od punktu centralnego Rynku Starego Miasta. Obszar badań nie obejmuje zatem całości Starego Miasta w rozumieniu administracyjnym (osiedle) i historycznym. W badaniu dążono do sprawdzenia oddziaływania Rynku Starego Miasta jako czynnika lokalizacji usług noclegowych w jego najbliższym otoczeniu przestrzennym, a także do oceny ciągłości funkcji turystycznej na analizowanym obszarze.

\section{Mieszkania na wynajem jako część usług noclegowych w Warszawie}

W oficjalnych statystykach w Polsce mieszkania i apartamenty na wynajem nie są uznawane jako odrębna kategoria zakwaterowania. Główny Urząd Statystyczny wyróżnia co prawda kategorię „pokoje gościnne/kwatery prywatne”, definiując je jako „rodzaj obiektu zakwaterowania turystycznego, który stanowią umeblowane pomieszczenia i lokale (z wyjątkiem kwater agroturystycznych) w mieszkaniach, domach i innych budynkach mieszkalnych należących do osób fizycznych lub prawnych (z wyjątkiem rolników), wynajmowane turystom na noclegi za opłatą"1, ale nie podaje danych dotyczących ich liczby. $Z$ tego względu, jak również z uwagi

${ }^{1}$ http://stat.gov.pl/metainformacje/slownik-pojec/pojecia-stosowane-w-statystyce-publicznej/311, pojecie. html?pdf=1 (3.11.2017). 
na znaczący brak danych, dokładna skala tego zjawiska jest w Polsce nieznana. Można przyjąć, że znaczna część mieszkań udostępnianych turystom tworzy tzw. szarą strefę.

Na świecie częściowo nieoficjalne wynajmowanie mieszkań turystom wyraźnie przybrało na sile w związku z dynamicznym rozwojem idei ekonomii współdzielenia (ang. sharing economy lub collaborative economy), którego początki określa się w literaturze na ok. 2010 r. Wówczas to, dwa lata po uruchomieniu serwisu Airbnb, wydana została książka Botsman i Rogersa pt. What's mine is yours: The rise of collaborative consumption, będąca manifestem ekonomii współdzielenia (Sans, Quaglieri-Domínguez 2016). Już jednak sześć lat później w książce o znamiennym tytule What's Yours Is Mine: Against the Sharing Economy” Slee (2016) obala mit „współdzielenia”, twierdząc, że Airbnb to działalność komercyjna, która pod „przykrywką” nośnie brzmiącej idei nastawiona jest na osiąganie zysków ${ }^{2}$, wytwarzając przy tym sporo problemów dla miast z rozwiniętą funkcją turystyczną. Celem niniejszego artykułu nie jest ani opisywanie zjawiska collaborative economy, ani analiza zagrożeń wynikających z rozwoju Airbnb w miastach, choć problematyka ta jest niezwykle interesująca i ważna (zob. np. Dredge i in. 2016; Dredge, Gyimóthy 2017).

Airbnb jest największym na świecie portalem służącym do wynajmowania prywatnych mieszkań turystom przez internet. Według oficjalnych danych podawanych przez serwis w Warszawie istnieje 4438 mieszkań na wynajem, z czego aż $76 \%$ ofert dotyczy całego mieszkania, a ponad $20 \%$ pokoi do wynajęcia. Znikomy udział stanowi dzielenie z gospodarzem wspólnego pokoju. W mieście zarejestrowanych jest ponad 2 tys. gospodarzy (hosts). Większość (67\%) wynajmuje więcej niż jedno mieszkanie/pokój, co pokazuje, że działalność ta ma w dużym stopniu komercyjny charakter. Airbnb podaje jednocześnie, że średnia liczba miejsc noclegowych w mieszkaniu wynosi 3,9, a wskaźnik obłożenia mieszkań (nie miejsc noclegowych) to $76 \%{ }^{3}$. Na tej podstawie można szacować, że liczba miejsc noclegowych dostępnych w mieszkaniach wynajmowanych przez Airbnb w Warszawie wynosi ponad 17 tys.

Jednocześnie, według oficjalnych statystyk, baza noclegowa w Warszawie obejmuje prawie 29 tys. miejsc noclegowych, z czego zdecydowana większość (88,5\%) to miejsca w obiektach hotelowych (hotele, motele, pensjonaty, inne obiekty hotelowe $)^{4}$. Według szacunków pojemność bazy noclegowej oferowanej na portalu Airbnb jest zatem równa 60\% wszystkich oficjalnie zarejestrowanych miejsc noclegowych w Warszawie. Dla porównania w Barcelonie na Airbnb dostępnych

\footnotetext{
${ }^{2}$ Jak podają Sans i Quaglieri-Domínguez (2016), wycena rynkowa przedsiębiorstwa Airbnb w 2014 r. była większa od wyceny największej na świecie sieci hotelowej InterContinental Hotels Group. W maju 2017 r. wycena rynkowa Airbnb wyniosła $31 \mathrm{mld}$ USD, https:/www.statista.com/statistics/339845/company-value-and-equity-funding-of-airbnb/ (3.11.2017).

${ }^{3}$ https://www.airdna.co/market-data/app/pl/default/warsaw/overview (2.11.2017).

${ }^{4}$ Dane BDL GUS za 2016 r.
} 
jest ok. 30 tys. miejsc, co stanowi prawie połowę miejsc dostępnych w sektorze hotelowym w tym mieście (Sans, Quaglieri-Domínguez 2016). To pokazuje, jak ogromna jest skala tego zjawiska.

\section{Charakterystyka obszaru badań}

Warszawskie Stare Miasto to jedyna w Warszawie „dzielnica turystyczna” w rozumieniu Getza (1993), Pearce'a (1998) czy Hayllara, Griffina i Edwardsa (2005). Część tego obszaru jest ograniczona dla ruchu samochodowego, a usługi, jakie tam dominują, to przede wszystkim usługi gastronomiczne (38\% wszystkich usług zinwentaryzowanych na obszarze w granicach murów obronnych w 2016 r.) i sklepy z pamiątkami (31\%) głównie dla turystów (Derek 2018). Badania ruchu turystycznego pokazują, że obszar ten od lat jest najczęściej odwiedzanym miejscem w Warszawie wśród turystów zagranicznych i niejednokrotnie także przez turystów krajowych. Przez obcokrajowców jest on wskazywany jako największa atrakcja turystyczna miasta (Ipsos 2016; Realizacja 2015) ${ }^{5}$.

Warto jednak dodać, że celem powojennej odbudowy Starego Miasta było stworzenie modelowego wówczas osiedla mieszkaniowego, ze zróżnicowaną strukturą społeczną, gdzie profesorowie uniwersyteccy zamieszkiwaliby tuż obok klasy robotniczej. Gdy Stare Miasto było wpisywane na Listę Światowego Dziedzictwa UNESCO w 1980 r., traktowano je jako obszar o funkcji mieszkalnej i miejsce ważnych wydarzeń historycznych, społecznych i duchowych ${ }^{6}$. Funkcje te nadal istnieją na tym terenie, od pewnego jednak czasu obserwuje się tendencję do ograniczania tu funkcji mieszkaniowej i odsprzedawania mieszkań agencjom wyspecjalizowanym w wynajmowaniu ich turystom bądź też do wynajmowania ich indywidualnie przez właścicieli.

\section{Metodyka badań}

Inwentaryzacja usług noclegowych na Starym Mieście objęła wszystkie dostępne typy zakwaterowania bez względu na ich oficjalny status, a zatem hotele, hostele, mieszkania na wynajem itp. Została ona przeprowadzona w listopadzie i grudniu 2016 r. i dotyczyła miejsca położenia obiektu, jego typu, dostępnej liczby miejsc noclegowych oraz ceny za noc. Pod pojęciem ceny rozumie się opłatę za jedną noc

\footnotetext{
${ }^{5}$ Niekiedy (np. w 2014 r.) turyści krajowi częściej deklarowali odwiedzanie Muzeum Powstania Warszawskiego. Wówczas Stare Miasto było drugim najczęściej odwiedzanym przez nich miejscem w Warszawie. To samo dotyczy pytania o to, co jest, zdaniem turystów, największą atrakcją turystyczną miasta. Obcokrajowcy rokrocznie wymieniają Stare Miasto, turyści krajowi zaś czasem Stare Miasto, a czasem Muzeum. ${ }^{6} \mathrm{http}: / /$ whc.unesco.org/en/list/30 (21.04.2016).
} 
za wynajęcie całego pomieszczenia w przypadku apartamentów, lub pokoju dwuosobowego bez dodatkowych usług w pozostałych przypadkach. Dane zbierano ze wszelkich możliwych serwisów internetowych udostępniających informacje o świadczeniu usług noclegowych, zwracając uwagę, by żaden obiekt nie został ujęty podwójnie. Zrezygnowano z inwentaryzacji w terenie, gdyż większości mieszkań i apartamentów wynajmowanych turystom nie da się zidentyfikować w ten sposób. Korzystano z Centralnego Wykazu Obiektów Hotelarskich, serwisów www.booking.com oraz www.airbnb.pl, a także wpisując w wyszukiwarkę internetową hasła związane $\mathrm{z}$ noclegami na badanym terenie i wchodząc następnie na strony konkretnych obiektów. Informacje o lokalizacji danego miejsca pozyskiwane były ze stron internetowych poszczególnych obiektów. Jeżeli na stronach internetowych nie podawano dokładnych adresów (sytuacja taka jest powszechna dla serwisu Airbnb, w przypadku którego pozyskanie danych o lokalizacji mieszkań było największym wyzwaniem), kontaktowano się z usługodawcami bądź korzystano ze zdjęć zamieszczanych w ogłoszeniach, aby rozpoznać konkretne miejsce. W razie braku informacji na temat dokładnego adresu (sytuacja ta dotyczyła 28 obiektów), lokalizacja danego lokalu została przypisana na środku ulicy, przy której obiekt ten był usytuowany.

\section{Wyniki}

Na badanym obszarze zidentyfikowano 225 obiektów noclegowych. Razem dysponowały one 1,5 tys. miejsc noclegowych (tab. 1). Zdecydowana większość, bo ponad dwie trzecie tych miejsc, zlokalizowana była w mieszkaniach i apartamentach na wynajem, które z kolei stanowiły ogromną większość obiektów zinwentaryzowanych na Starym Mieście. Oba hotele to skategoryzowane jako pięciogwiazdkowe obiekty o charakterze hoteli butikowych (Hotel Belotto i Mamaison Hotel Le Regina Warsaw). Oba zajmują zabytkowe pałace i stosunkowo niedawno zostały otwarte (odpowiednio 2016 r. i 2004 r.). Są to największe obiekty na badanym obszarze, mieszczące w sumie $11,5 \%$ miejsc noclegowych. To niewiele mniej niż cztery znajdujące się tu hostele (tab. 1).

Obiekty noclegowe występowały przede wszystkim w bliskiej odległości od Rynku Starego Miasta. Aż $43 \%$ obiektów noclegowych zlokalizowanych było w odległości do $300 \mathrm{~m}$ od środka rynku (ryc. 1 i 2). Na tym obszarze obiekty noclegowe były rozmieszczone w miarę równomiernie.

Jak pokazano na rycinach 1 i 2, wraz z oddalaniem się od rynku liczba obiektów maleje, by ponownie wzrosnąć w przedziale pomiędzy 800 a $1000 \mathrm{~m}$ (29\% obiektów), co wiąże się z koncentracją obiektów przy ulicy Bednarskiej, na Mariensztacie oraz na Nowym Mieście. Zdecydowany spadek liczby obiektów 


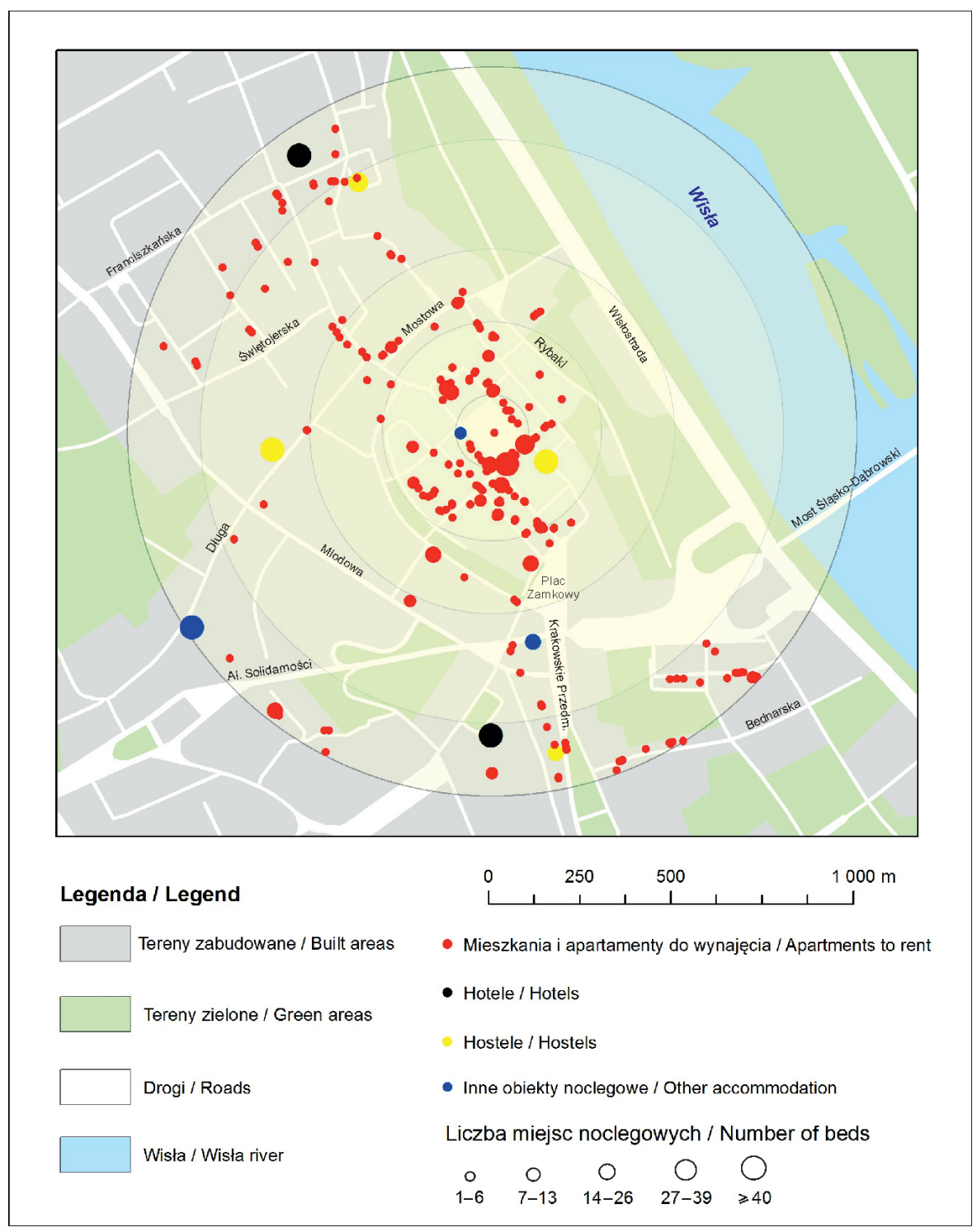

Ryc. 1. Lokalizacja i wielkość obiektów noclegowych na obszarze o promieniu 1 km od punktu centralnego w Rynku Starego Miasta w Warszawie (2016; n = 225)

Fig. 1. Distribution and size of accommodation establishments within a radius of the Old Town Market Square in Warsaw $(2016, \mathrm{n}=225)$

Objaśnienia: ekwidystanty o promieniu: 100, 300, 500, 800 i $1000 \mathrm{~m}$

Explanation: The figure shows the radius of 100, 300, 500, 800 and $1000 \mathrm{~m}$ Źródto: Dycht (2017); zmienione.

Source: adapted from Dycht (2017). 
Tab. 1. Obiekty noclegowe w promieniu $1 \mathrm{~km}$ od Rynku Starego Miasta w Warszawie Table 1 . Accommodation within a radius of $1 \mathrm{~km}$ from the Old Town Market Square in Warsaw

\begin{tabular}{|l|c|c|c|c|c|c|}
\hline \multirow{2}{*}{$\begin{array}{c}\text { Rodzaj obiektu } \\
\text { noclegowego } \\
\text { Type of accommodation }\end{array}$} & \multicolumn{2}{|c|}{$\begin{array}{c}\text { Obiekty } \\
\text { Establishments }\end{array}$} & \multicolumn{2}{c|}{$\begin{array}{c}\text { Miejsca noclegowe } \\
\text { Number of beds }\end{array}$} & $\begin{array}{c}\text { Mediana liczby } \\
\text { miejsc noclegowych } \\
\text { Median value of } \\
\text { number of beds }\end{array}$ & $\begin{array}{c}\text { Mediana ceny } \\
\text { za dobę (w zł) } \\
\text { Median value } \\
\text { of price per night } \\
\text { (in PLN) }\end{array}$ \\
\hline & $\begin{array}{c}\text { Liczba } \\
\text { Number }\end{array}$ & $\%$ & $\begin{array}{c}\text { Liczba } \\
\text { Number }\end{array}$ & $\%$ & 90 & 360 \\
\hline Hotele / Hotels & 2 & 0,9 & 179 & 11,5 & 43 & 150 \\
\hline Hostele / Hostels & 4 & 1,8 & 191 & 12,3 & 249 \\
\hline $\begin{array}{l}\text { Mieszkania i aparta- } \\
\text { menty na wynajem } \\
\text { Apartments to rent }\end{array}$ & 215 & 95,6 & 1058 & 68,1 & & 194 \\
\hline $\begin{array}{l}\text { Inne obiekty } \\
\text { Other accommodation }\end{array}$ & 4 & 1,8 & 126 & 8,1 & 33 & - \\
\hline Razem / Total & 225 & 100 & 1554 & 100 & - & 43 \\
\hline
\end{tabular}

Źródto: opracowanie własne na podstawie: Dycht (2017).

Source: adapted from: Dycht (2017).

noclegowych między 400 a 800 m wynika między innymi z faktu, iż w tej strefie zmniejsza się intensywność zabudowy mieszkaniowej, występują większe ulice i szlaki komunikacyjne, pojawia się zabudowa przeznaczona na cele publiczne i biurowe. Na spadek liczby obiektów wpływa również fakt, iż w tej odległości obszar badawczy zaczyna sięgać od strony wschodniej do Wisły (ryc. 1). Obiekty, które występują w strefie pomiędzy 400 a 800 m, koncentrują się w ogromnym stopniu wzdłuż najbardziej popularnej trasy turystycznej, prowadzącej od Traktu Królewskiego do Nowego Miasta. Na obszarze położonym na południowy zachód od rynku baza noclegowa jest znikoma.

Na Starym Mieście dominują małe i bardzo małe obiekty noclegowe. Wartość mediany miejsc noclegowych dla badanych obiektów wynosi 4 . Wynika to z ogromnej dominacji mieszkań do wynajęcia i apartamentów (tab. 1). Mediana dla pozostałych obiektów razem (hotele, hostele i inne obiekty) to 44. Pomimo że jest to znacznie wyższa wartość, wciąż są to małe obiekty noclegowe. Poza kilkoma dużymi apartamentami oraz jednym hotelem większe obiekty noclegowe występują dalej od rynku - dotyczy to obu hoteli, pozostałych trzech hosteli, jak i największego obiektu zaklasyfikowanego jako „inny obiekt noclegowy” (pokoje gościnne w Federacji Związków Zawodowych „Metalowcy”) (ryc. 1).

\footnotetext{
${ }^{1}$ Są to noclegi w Domu Literatury, Instytucie Historii PAN, Federacji Związków Zawodowych „Metalowcy” oraz Castle Inn (obiekt z 48 miejscami noclegowymi o cechach hotelu butikowego).
} 


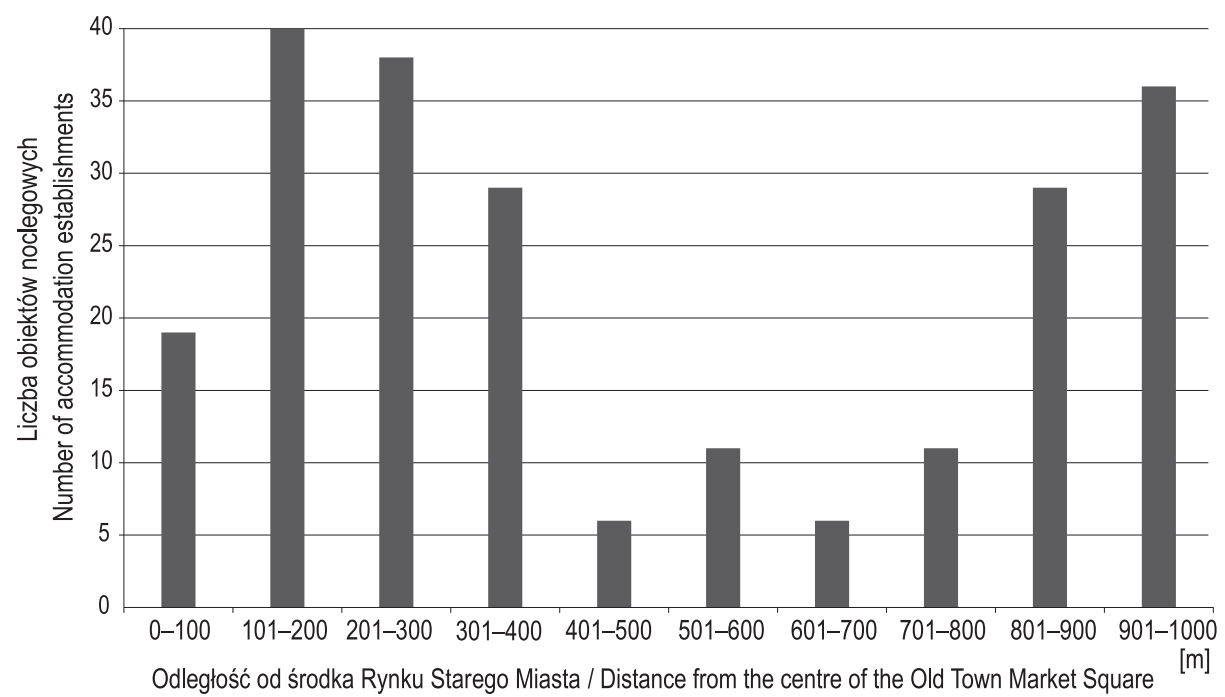

Ryc. 2. Liczba obiektów noclegowych według przedziałów co 100 m od środka Rynku Starego Miasta w Warszawie (2016, $\mathrm{n}=225)$

Fig. 2. Number of accommodation establishments every $100 \mathrm{~m}$ from the Old Town Market Square in Warsaw $(2016, \mathrm{n}=225)$

Źródto: Dycht (2017).

Source: Dycht (2017).

Przeciętna cena wynajmu mieszkania lub pokoju dwuosobowego w obiektach zbiorowego zakwaterowania na badanym obszarze wynosi prawie $250 \mathrm{zl}$. Cena noclegu w hotelach jest prawie o $70 \%$ wyższa niż wynajem mieszkania, ale biorąc pod uwagę pięciogwiazdkowy standard obu hoteli, nie jest to znacząca różnica. Usługi noclegowe w pozostałych obiektach, w tym hostelach, są tańsze (tab. 1). Badania wykazały, że rosnąca odległość od rynku nie powoduje spadku cen usług noclegowych, choć pewną zależność między tymi zmiennymi można dostrzec. Po pierwsze, wyraźnie najwyższe ceny charakteryzują obiekty położone w samym centrum badanego obszaru (w rynku i w jego bezpośrednim sąsiedztwie). Po drugie, mediany cen noclegów znajdujących się w odległości do 400 m są wyższe od mediany dla wszystkich obiektów, a ceny dla obiektów zlokalizowanych w odległości większej niż 400 m - niższe (ryc. 3). Nie można jednak jednoznacznie stwierdzić, że ceny usług noclegowych systematycznie maleją wraz z odległością od Rynku Starego Miasta. Jest to prawdopodobnie spowodowane faktem, że obszar wybrany do badań ma zbyt małą powierzchnię, aby wychwycić taką zależność, i prawie 


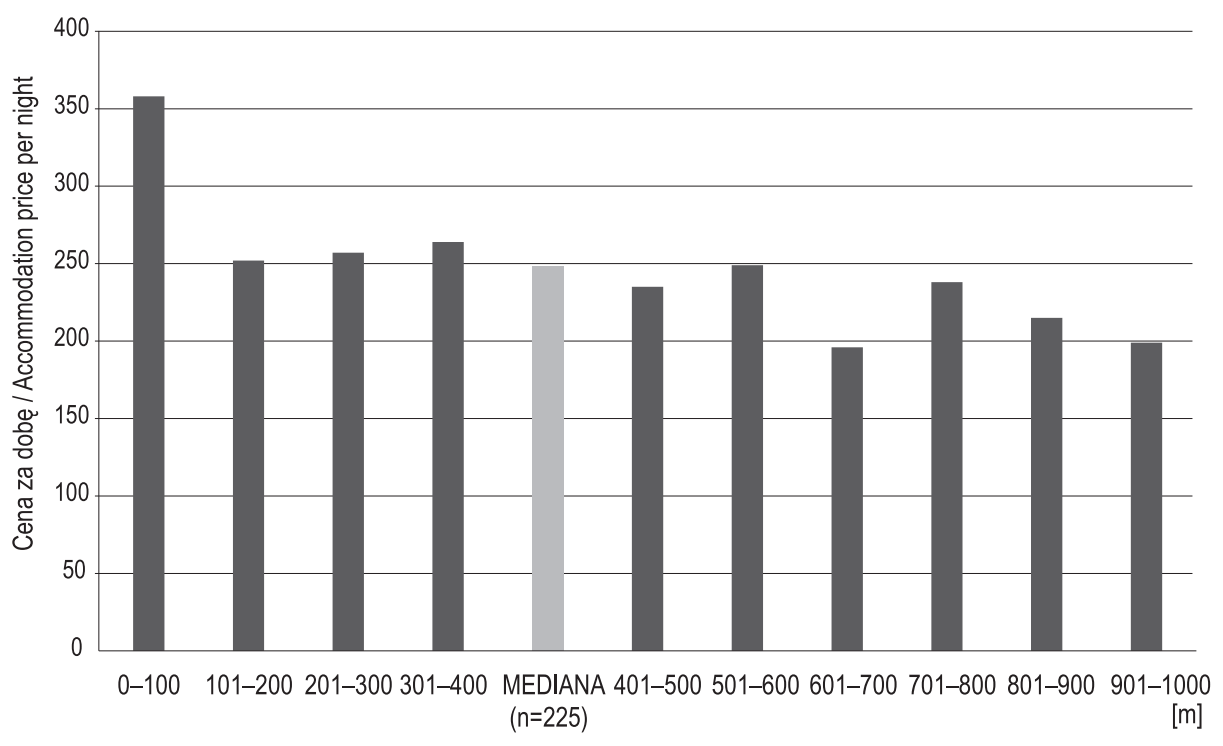

Odległość od środka Rynku Starego Miasta / Distance from the centre of the Old Town Market Square

Ryc. 3. Średnia cena usług noclegowych w zależności od odległości od środka Rynku Starego Miasta w Warszawie (2016; $\mathrm{n}=225)$

Fig. 3. Average price of accommodation by distance from the centre of the Old Town Market Square in Warsaw $(2016, \mathrm{n}=225)$

Źródto: opracowanie własne na podstawie: Dycht (2017).

Source: adapted from: Dycht (2017).

w całości położony jest na obszarze cieszącym się zainteresowaniem turystów. Jest to zgodne z wynikami innych badań, w świetle których dla cen usług hotelowych nie zawsze jest istotne, jak daleko hotel znajduje się od punktu centralnego w mieście, lecz czy znajduje się on w centrum, czy poza centrum miasta (Napierała, Adamiak 2014). Na podstawie analizy stron internetowych, wykonanej w trakcie tworzenia bazy danych do badania, oraz po przeglądzie zdjęć poszczególnych obiektów wydaje się, że cena usług zależy głównie od standardu i oferowanej powierzchni mieszkalnej w obiekcie. Potwierdzenie tej obserwacji wymagałoby jednak przeprowadzenia odrębnych badań. 


\section{Podsumowanie}

Niezwykle dynamiczny rozwój tzw. ekonomii współdzielenia w ciągu ostatnich lat jest spowodowany wieloma czynnikami. $Z$ jednej strony wymienić można powszechne wykorzystanie urządzeń i technologii mobilnych oraz łatwość wejścia na rynek firm typu start-up, z drugiej zaś globalny kryzys ekonomiczny z 2008 r. i związane z tym poszukiwanie alternatyw w stosunku do nadmiernej konsumpcji (Dredge, Gyimóthy 2015). Ekspansja tego zjawiska wywarła ogromny i raczej nieodwracalny wpływ także na gospodarkę turystyczną, w tym w dużej mierze na sektor usług noclegowych. Zmiany w tej dziedzinie mają charakter zarówno ilościowy (zwiększenie pojemności turystycznej obszaru), jak i jakościowy (bardziej zróżnicowana oferta, nowe miejsca lokalizacji usług). Widać to doskonale na przykładzie Starego Miasta w Warszawie, gdzie jeszcze kilkanaście lat temu usługi noclegowe były rzadkością. Obecnie pojemność obszaru wyznaczonego przez ekwidystantę o promieniu $1 \mathrm{~km}$ od środka Rynku Starego Miasta wynosi ponad 1,5 tys. miejsc noclegowych. Aż 2/3 oferowanych miejsc przypada na mieszkania i apartamenty na wynajem, co odpowiada pojemności $10 \%$ wszystkich hoteli zlokalizowanych w dzielnicy Śródmieście kilka lat temu (Derek i in. 2013). Obiekty te znajdują się w znacznej mierze w bezpośrednim sąsiedztwie Rynku Starego Miasta (do 300 m), nie można jednak stwierdzić, że wraz z oddalaniem się od rynku ich liczba maleje. Jest to prawdopodobnie spowodowane zbyt małą powierzchnią objętą badaniami.

\section{Literatura}

Adamiak M., Napierała T., 2013, Przestræenne zróżnicowanie cen ustug noclegowych w tódzkim obszarze metropolitalnym, Prace Geograficzne, 134, 37-50.

Ashworth G.J., 1989, Urban tourism: An imbalance in attention, Progress in Tourism, Recreation and Hospitality Management, 1, 33-54.

Ashworth G.J., Tunbridge J.E., 2000, The tourist-historic city, Elsevier Science, Oxford.

Cohen-Hattab K., 2004, Historical research and tourism analysis: The case of the tourist-historic city of Jerusalem, Tourism Geographies, 6 (3), 279-302.

Derek M., 2018, Spatial structure of tourism in a city after transition: The Case of Warsaw, Poland, [w:] D. Müller, M. Więckowski (red.), Tourism in transitions. Geographies of tourism and global change, Springer, Cham, 157-171.

Derek M., Duda-Gromada K., Kosowska P., Kowalczyk A., Madurowicz M., 2013, Problemowe i problematyczne ABC turystyki w Warszawie, Prace Geograficzne, 134, 7-36.

Dredge D., Gyimóthy S., 2015, The collaborative economy and tourism: Critical perspectives, questionable claims and silenced voices, Tourism Recreation Research, 40 (3), 286-302. 
Dredge D., Gyimóthy S. (red.), 2017, Collaborative economy and tourism, Springer, Cham.

Dredge D., Gyimóthy S., Birkbak A., Jensen T.E., Madsen A.K., 2016, The impact of regulatory approaches targeting collaborative economy in the tourism accommodation sector: Barcelona, Berlin, Amsterdam and Paris, Impulse Paper No. 9 prepared for the European Commission DG GROWTH, Aalborg University, Kopenhaga.

Dycht K., 2017, Lokalizacja ustug noclegowych na Starym Mieście w Warszawie, praca licencjacka przygotowana na Wydziale Geografii i Studiów Regionalnych, Uniwersytet Warszawski, Warszawa.

Egan D., Nield K., 2000, Towards a theory of intraurban hotel location, Urban Studies, 37 (3), 611-621.

Getz D., 1993, Planning for tourism business districts, Annals of Tourism Research, 20 (4), 583-600.

Hayllar B., Griffin T., Edwards D. (red.), 2008, City spaces - tourist places: Urban tourist precincts, Butterworth-Heinemann, Oxford-Burlington.

Ipsos, 2016, Raport z badania opinii turystów odwiedzajqcych Warszawę w 2016 roku, raport przygotowany dla Urzędu Miasta Stołecznego Warszawy, listopad 2016, Ipsos Loyalty, Warszawa.

Kowalczyk A., 2001a, Definicja i przedmiot badań geografii hotelarstwa, Turyzm, 11 (2), 5-22.

Kowalczyk A., 2001b, Geografia hotelarstwa, Wydawnictwo Uniwersytetu Łódzkiego, Łódź.

Kowalczyk A., Derek M., 2010, Zagospodarowanie turystyczne, Wydawnictwo Naukowe PWN, Warszawa.

Matczak A. (red.), 2004, Lokalizacja hoteli w krajowych metropoliach Europy Środkowo-Wschodniej, Łódzkie Towarzystwo Naukowe, 33.

Matczak A., 2004, Metodologia badań nad lokalizacja hoteli, [w:] A. Matczak (red.), Lokalizacja hoteli w krajowych metropoliach Europy Środkowo-Wschodniej, Łódzkie Towarzystwo Naukowe, Śladami Nauki, 33, Łódź, 11-43.

Nalej M., 2014, Rozmieszczenie obiektów noclegowych w Łodzi w 2013 roku w świetle miar centrograficznych, Acta Universitatis Lodziensis. Folia Geographica Socio-Oeconomica, 16, 133-148.

Napierała T., Adamiak M., 2014, Odległość od centrum miasta jako determinanta cen ustug hotelowych, Studia Oeconomica Posnaniensia, 2 (3), 41-54.

Pawlicz A., Napierala T., 2017, The determinants of hotel room rates: An analysis of the hotel industry in Warsaw, Poland, International Journal of Contemporary Hospitality Management, 29 (1), 571-588.

Pearce D.G., 1998, Tourist districts in Paris: Structure and functions, Tourism Management, (19) 1, 49-65.

Realizacja, 2015, Raport z badania opinii turystów odwiedæajq̨cych Warsæawę w 2015 r., Realizacja Sp. z o.o., Warszawa.

Rotter K., 2004, Ekonomiczne znaczenie lokalizacji hotelu w præestræeni miasta, Turystyka i Hotelarstwo, 5, Łódź, 27-36.

Rotter-Jarzębińska K., 2011, Baza noclegowa - stan i kierunki rozwoju, [w:] M. Mika (red.), Kraków jako ośrodek turystyczny, IGiGP UJ, Kraków, 161-180. 
Sans A.A., Quaglieri-Domínguez A., 2016, Unravelling Airbnb: Urban perspectives from Barcelona, [w:] A.P. Russo, G. Richards (red.), Reinventing the Local in Tourism: Producing, Consuming and Negotiating Place, Channel View Publications, Buffalo-New York, 209-228.

Slee T., 2016, What's yours is mine: Against the Sharing Economy, Or Books, New York.

Włodarczyk B., 2015, Hotele w præestrzeni miejskiej Łodzi, Turyzm, (25) 2, 63-75.

\author{
Marta Derek \\ Uniwersytet Warswawski \\ Wydziat Geografii i Studiów Regionalnych \\ Krakowskie Przedmieście 30, 00-927 Warszawa \\ m.derek@uw.edu.pl \\ Karolina Dycht \\ Uniwersytet Warszawski \\ Wydziat Geografii i Studiów Regionalnych \\ Krakowskie Przedmieście 30, 00-927 Warszawa \\ k.dycht@student.uw.edu.pl
}

